\title{
The Gober Team as One of the New Waste Management Systems (WMS) in Bandung City
}

\author{
Lia Muliawaty \\ Faculty of Social Sciences and Politics \\ Pasundan University \\ Bandung, Indonesia \\ liamuliawatyunpas@gmail.com
}

\begin{abstract}
Waste management system (WMS) is complex problem in most of big cities in Indonesia, including Bandung City. Even the problem of WMS in Bandung City has become a classic problem. Therefore, various WMS have been done by new Mayor Bandung since he was elected since 2013.

In fact, most of Bandung City's WMS is not successful. There are many factors that cause the programs to be unsuccessful. The waste reduction policy is top down model from government to the society. For example, adopting a Western waste bin from a plastic bag which does not match the type of household waste in Bandung.

The new WMS of Bandung City is self-management system by Perusahaan Daerah (PD) Kebersihan. In addition, the prevention program of waste carried out up to the sub districts or Kelurahan level with the establishment of a special team called as Tim Gorong-gorong dan Kebersihan (abbreviated as Tim Gober). The Tim Gober's main task is to clean up the garbage in each Kelurahan such as in the parks, streets, ditches and street gutters.

The existence of Gober team causes the involvement of the community to be reduced such as eliminating community service or Kerja Bakti. Whereas, community participation as a main producer of waste is very important. Therefore, government policy on WMS should start from the community.
\end{abstract}

Keywords - community; top-down model; policy, waste management system (WMS)

\section{INTRODUCTION}

\section{Introduction}

The solid waste is a universal problem faced by many countries in the world, especially developing countries such as Indonesia which is still low solid waste processing technology and minimal infrastructure. There are many factors that cause solid waste problems difficult to overcome by most cities in developing countries such as Bandung City. Even solid waste in Bandung City has become a classic problem. This is due to the following factors: The phenomenon of municipal solid waste management (MSWM) has become a major developmental challenge to most cities in developing countries. This is more problematic in developing countries
[1]; According to Mensah (2006) solid waste generation is related with ubiquitously around human settlement. Management of these generated solid wastes is a main problem for all concerned authorities all over the world. Rapid population growth, increasing urbanization, fast development of infrastructure, changing lifestyles and economic conditions increased the solid waste generation rate and composition. [2]; Robinson (1986) states that the notion of municipal solid waste also known as urban solid waste or garbage or trash includes discarded materials such as paper, plastic, cans, glass, metal, dirt, ash, dead animals, etc., and usually collected by local government authorities. Municipal solid waste involves activities associated with six basic principles of solid waste generation, storage, collection, transfer and transport, processing and disposal. [2]

Therefore, various Solid waste Management System (WMS) have been done by new Mayor Bandung since he was elected since 2013. In fact, most of Bandung City's WMS is not successful. There are many factors that cause the programs to be unsuccessful. One of the efforts to overcome the solid waste is the Community Participation (PSM) approach. These efforts have been carried out by several countries, including in Ghana and India. The program is called public-private partnership (PPP) [1]. PPP is considered quite successful and effective in solving the solid waste problem. Though there is no single readymade solution to control the solid waste problems, PPP has been advanced to serve as a panacea. This suggests that PPP is a way of mitigating the challenges associated with solid waste management [1]. In tackling garbage that the participation of the public or community is very important as stated below: public participation and awareness is an important issue in achieving an appropriate solid waste management [2]; "... community must implement programs to reduce solid waste, which include: 1) educating citizens about source reduction, 2) reducing the frequency of collection in order to encourage people to reduce solid waste production, frequency of solid waste collection will be twice or thrice a week [3].

The WMS consist of many program such as plastic solid waste bag program, establishment of a special team called as Tim 
Gorong-gorong dan Kebersihan (abbreviated as Tim Gober) with main task is to clean up the garbage in each Kelurahan such as in the parks, streets, ditches and street gutters. Basically, community involvement is very important because humans are garbage producers. In addition, the garbage problem is caused by some people who do not care about the environment or they have a bad habit of disposing of garbage, such as disposing household garbage in ditches, rivers and public spaces. Some street vendors throw garbage in ditches or sidewalks. Some people throw garbage in the gutter when it rains. As a result the garbage clogs ditches, sewers or rivers and it causes flooding. Even some pedestrians, bikers, motor drivers and car drivers throw garbage into the street. The existence of Gober team causes the involvement of the community to be reduced. Whereas, community participation as a main producer of solid waste is very important. Therefore, government policy on WMS should start from the community.

\section{Literature Review}

\subsection{Definition and Type of Solid waste}

There is a lot of definitions about solid waste for example: The definition of municipal solid waste (MSW) is open to administrative interpretation which may vary between countries, agencies and even local jurisdictions, however, the MSM that is mentioned in this study refers to the solid waste management at residences, commercial establishments (i.e offices, retail shops, restaurants), and institutions (i.e hospitals and schools) but dose not include construction / demolition debris, automobile scrap or medical / pathological solid waste [4].

Most developing countries are hoarding solid waste in land fill but it will no longer be applied in the future because of many constraints, including land and location constraints, causing pollution of the soil, water and environments, causing bad odor and infectious diseases. In addition, new regulations on solid waste collection will be applied as follows: "Even though landfilling still prevails in many countries as a result of the newly adopted regulations it has to be limited in the future" [4].

\subsection{Public Policy}

We recommend that the government's policy on solid waste should involve all stakeholders, especially the community as one of its stakeholders and target. Basically, the public policy sector is dynamic and complex due to the various actors and interests. The public sector consisting of many actors and interests requires a complete method to solve the problems. For example, when the government faces the problem of municipal solid waste, the government will face with many different actors and interests [5]; Donelly identifies the specific characteristics of the public sector that complicate the quality of the implementation principle. He claims that the quality itself has a completely different meaning in the public compared to the private sector. That is why the quality improvement in the public sector is limited to the improvement of the internal organization's operations, rather than improving the final services in order to offer new and more services. [6] According to David Easton who defines the public policy as the allocation of values to the whole society as a whole; Carl Friedrich cautioned the importance of the policy concept of having certain clear suggestions, objectives, and objects; Thomas R. Dye said that public policy has four traits, namely regulative, organizational, distributive, and executive. [7]; Some scholars have simply understood the policy. Other have spelled out definitions that focus on the specific characteristics of public policy. Lowi and Ginsburg (1996), for example, define public policy as 'an officially expressed intention backed by a sanction', as a course of action (or inaction), a public policy can take the form of "a law, a rule, a statute, an edict, a regulation or an order." [8]

\subsection{Implementation}

In essence implementation is a form of intersection between the various sciences, so that in the implementation of a program - such as solid waste management in the city of Bandung is a complex - need to use various approaches that are holistic. According to Schofield and Sausman (2004) stated that implementation studies are to be found at the interaction of public administration, organizational theory, public policy research, and political sciences study." [9]

During this time many policies of solid waste management by Bandung City government done using top - down model/theory. However, in its implementation it is a failure, for example, plastic garbage programs adopted from the Western countries whose majority of the population is educated, concerned about the environment and health, discipline of regulations etc. In contrast to our community, including heterogeneous of Bandung citizens, uneven educational background, low concern for the environment and health, lack of discipline to regulations including waste regulations. So the program is difficult to implement. There are statements of factors that need to be regulated in the implementation of public policy, namely: "Public policy varies according to the intervened region, the objectives to be achieved, the target group, and the expected substance of change." [10] In the perspective of public policy that solid waste programs in Bandung City refers to the top-down model/theory which the model started from the assumption that policy implementation starts with a decision made by central government. [9] While the target community is not involved. Whereas an ideal program implementation is to include the community as one of the stake holders. Ideally, solid waste policies should use the Bottom-up model in order to make public participation more dominant. The reason is that the solid waste problem is a social issue, that is the behavior or habit of the people in disposing of garbage. According to Stich and Eagle state the public order should be more than it is. Community involvement has a higher meaning, as a medium of learning together between government and society. "[10]

However, there are new and different perspectives that come from third-generation implementation researcher. They more 
emphasis on clear hypotheses, find proper operationalization and produce sufficient empirical observations to test these hypotheses. Some researchers who follow this approach, among others de Leon and O'Toole. According to Goggin et al. (1990) that the third generation of implememtation research tried to bridge the gap between Top-down and Bottom-up approaches by incorporating the insight of the two camps into their theoritical models. At the same time, the self-proclaimed goal of third generation research was to be more scientific the previous two in its approach to the study implementation."[9] The trend is now the implementation of multiple agencies involving many actors and institutions. Knight and Stivers (1998) urged administrators to engage citizens. Community involvement should be seen as a "significant investment." [9] This confirms that the role of the community will affect the implementation process.

\section{Result and Discussion \\ 3.1 Plastic Waste Bag Program}

In fact, most of Bandung City's WMS is not successful. The new Mayor of Bandung City has several policies on solid waste management, such as plastic solid waste bag to separate organic and non organic waste and plastic shopping bag program. These programs aim to tackle the increasing number of plastic solid waste. The plastic shopping bag is an effort to reduce the use of shopping plastic bag by consumers. Consumers have to pay Rp. 200 / plastic shopping bag at shop or they bring their own. The program only runs for a few months and now the plastic bag is back free.

The main purpose of programs is to reduce plastic solid waste causing drains and clogged streams as well as floods. It is estimated that the amount of plastic solid waste in Bandung reaches 200 tons / day. The above figures will continue to grow in line with the increase of plastic shopping bag users because it is practical and inexpensive. In addition to plastic solid waste problem also food packaging from styrofoam material is a big problem for Bandung City especially Styrofoam waste that is dumped into the river because it can cause flooding.

Basically, the failure of the implementation of the plastic solid waste bag program is caused by various factors, such as the number of plastic solid waste bag, the distance far away from house, the construction and the materials are not strong, plastic bags are rarely picked up or replaced, due to vandalism and others. Ironically plastic solid waste bag is used to accommodate all types of solid waste, including household garbage and solid waste that causes it damaged. In abroad plastic waste bag or plastic bins are intended to accommodate light waste such as bottles, food wrappers, plastic bottles and food packaging. They are placed in public spaces such as downtown areas, shopping centers, bus stations, railway stations, airports. While in Bandung City the plastic waste bag is placed also in housing complexes that produce heavy or wet household garbage. Therefore, plastic waste bag program fail in their application.

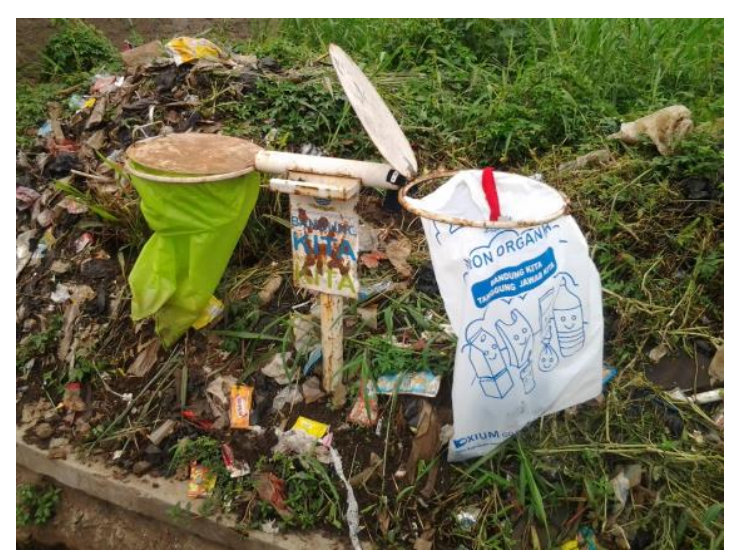

Fig.1 Plastic waste bag program fails in its application because it does not meet the needs and types of solid waste.

\subsection{Final Processing Place (Tempat Pemrosesan Akhir)}

Bandung solid waste dumped into the final processing place (Tempat Pemrosesan Akhir abbreviated TPA) in the Sarimukti Village, West Bandung Regency. Previously solid waste disposed to TPA Leuwi Gajah, Cimahi City, but the place was closed. In Leuwi Gajah landfill, there has been a landslide of garbage that killed 156 people who lived around the landfill site in 2005. The TPA Sarimukti covers 25 hectares and is also used to collect solid waste from Cimahi City and West Bandung Regency. So, the volume of solid waste dumped in the TPA Sarimukti landfill is very large volume.

Basically, the solid waste problem is closely related to the population of a city. Rapid population growth causes the volume of solid waste to increase. Based on the Central Bureau of Statistics (Biro Pusat Statistik) the population of Bandung City is 2.5 million as 2016. The amount does not include temporary residents, migrants from other cities such as student and merchant, workers from outside the city which is quite a lot. This is the impact of urbanization. So the volume of garbage continues to increase, especially during the weekend because the city visited by many domestic tourists mostly from Jakarta. Bandung City is the capital city of West Java Province which function as a center of government administration, business city, education city, tourism city, culinary city and others. These activities can be the attraction of immigrants from various cities such as from West and South Sumatra who became a clothing trader in Bandung. Most street vendors come from outside Bandung City.

In fact, the main problem faced by big cities, such as Bandung City is the problem of urbanization causing various impacts including increasing the volume of solid waste. In 2017, the volume of solid waste in Bandung is 1,700 tons / day. The amount of plastic solid waste reaches about 200 tons / day. It consist of 57 percent organic and 43 percent non organic solid wastes. While in 2013 the volume of solid waste is 1300 tons / day. This shows that the volume of solid waste in Bandung City continues to increase. While the capacity of the TPA 
Sarimukti about 1,100 tons / day. There is a difference of solid waste volume which is about 400 tons / day. To overcome the excess volume above, it is necessary to do innovative solutions. Solid waste innovation consists of garbage bank, compost process, bio digester, and bio conversion with maggot. Through these innovations, the volume of solid waste dumped in the TPA can be reduced. But in the implementation of the above innovations have not been optimal.

Distance from the city of Bandung to TPA Sarimukti about 45 kilometers. The distance is quite far and cause high transportation costs and limited freight frequency. In addition, in 2017 there are several increase in operational costs, namely tipping fee from Rp.29.000 / ton to Rp. 50.000 / ton. Negative Impact Compensation Cost (Kompensasi Dampak Negatif) for

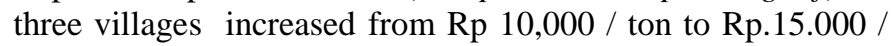
ton. The increase in operating costs caused the solid waste budget in 2017 to be 125 billion.

\subsection{Habit of Disposing Garbage of Bandung Citizen}

Increased garbage volume on roads and sidewalks is also caused by pedestrians, motor cycle and car driver who dump garbage on the highways, such as beverage cans, mineral bottles, cigarette packs, food wrappers and the like. Some passengers of public transport called "Angkot" also throw garbage in the vehicle. In fact, has provided a solid waste basket but not used by passengers.

Bad habit of littering are done by many people, whether poor or rich, uneducated or educated, students or workers and so forth. The above symptoms indicate that the solid waste problem in Bandung City has been very severe or complex because almost everyone did. This has caused the volume of solid waste continues to increase and the environment becomes dirty. Meanwhile, government of Bandung City does not have adequate infrastructure, especially modern equipment. Therefore, the participation of the community is vital in tackling the solid waste problem because of the increasingly complex solid waste problem, especially related to its human being as a solid waste producer.

\subsection{Regional Company Cleanliness (PD. Kebersihan)}

During this solid waste management in the city of Bandung is handled by the Regional Company (Perusahaan Daerah) called $P D$. Kebersihan. Legal aspect of $P D$. Kebersihan is the Local Regulation (Peraturan Daerah) of Bandung Number 14 Year 2011. In 2017 based on Mayor Regulation (Peraturan Walikota) there is a change of Work Organization Structure (Struktur Organisasi Tata Kerja) that solid waste management is self-management. The position of PD. Kebersihan is as the executor performing the duties of the Environmental Hygiene Department (Dinas Lingkungan Hidup dan Kebersihan). The changes in the above structure are considered to improve the work of $P D$. Kebersihan and overcome the problem of solid waste.

PD. Kebersihan has 160 Temporary Disposal Sites (Tempat Penampungan Sementara abbreviated TPS) among which 10
TPS can process Reduce, Reuse, Recycle (3 R). It also has 1 Integrated Temporary Disposal Site (Tempat Penampungan Sementara Terpadu abbreviated TPST) at Babakan Sari, Kiaracondong Sub-district, which can process 3R and bio digester that can process organic household solid waste into gas. Production capacity is still small that is 300 kilograms / day. PD. Kebersihan has operational vehicle facilities 105 trucks, 12 pick up trucks, 50 tricycles and 203 containers. The total number of employees is 1,679 people including 648 street sweepers, outsourced road sweepers 95 people and transport officers 219 people. However, infrastructure is still minimal when compared with increasing the volume of solid waste.

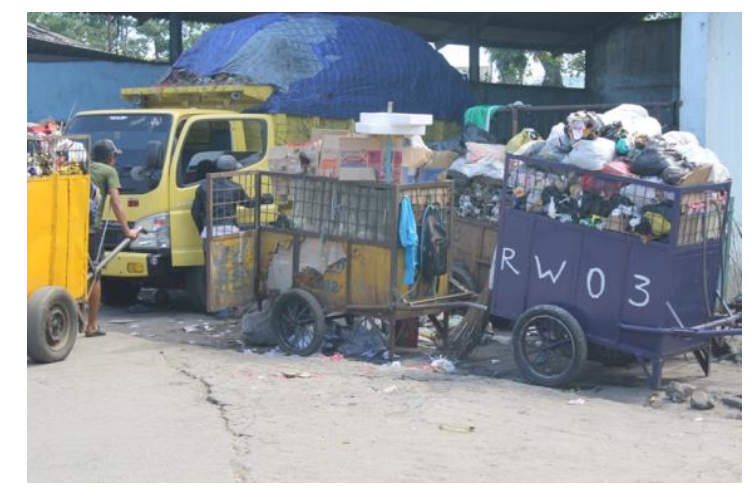

Fig.2 Integrated Temporary Disposal Site (TPST) in Babakan Sari, Kiaracondong Sub-district, which can process $3 \mathrm{R}$ and bio digester. Potential of bio digester facility not yet optimal.

\subsection{The Gober Team}

In 2016 the government of Bandung City formed the Development Innovation Program and Regional Empowerment (Program Inovasi Pembangunan dan Perberdayaan Kewilayahan abbreviated PIPPK) with its purpose for equalization of development and cleanliness to the smallest level. Its activities in Rukun Warga and Kelurahan. Each Kelurahan has Tim Gorong-grong dan Kebersihan called as Tim Gober. Tim Gober paid by PIPPK is Rp.1.250.000/month/people.

Tim Gober in Mekar Mulya Village, District Panyileukan, which consists of 27 members. Of that number as many as 3 members served in the administrative office in the Kelurahan. Kelurahan Mekar Mulya has 6 Rukun Warga. Tim Gober 's work schedule starts at 08.00 am until $02.00 \mathrm{pm}$. They work from Monday to Saturday. Tim Gober is divided into two, the "Atas" team in charge of cleaning up the garbage on the ground and the team "Bawah" in charge of cleaning ditches and gutters. Although divided into two teams but they work together. Tim Gober works in every Rukun Warga area to clear streets, parks, fields, ditches, gutters and the like. Unless there is a problem that needs to be solved immediately, such as flood it can be re-scheduled or additional hours of work.. Every morning the Tim Gober checks and cleans the main streets and ditches located in Kelurahan area. The goal is for 
the environment in the Kelurahan area clean and beautiful. The existence of the is Tim Gober very positive because they clean the environment and picking up solid waste.

But the Tim Gober cause the role of society in maintaining environmental cleanliness and solid waste become reduced. People rely on environment and solid waste cleanliness to the team. This has an negative impact on community involvement in cleaning and reducing solid waste. Whereas the role of society is very important in tackling solid waste in Bandung City.

\section{Conclusion}

Solid waste is a complicated problem for the government of Bandung City. Various programs have been carried out by the government of Bandung City, including adopting the bin which made of plastic bags and plastic shopping bags. However, some of these policies did not go smoothly in their implementation. While the problem of solid waste is a common problem that includes its people as waste producer and target of program.

One of the cleanliness and solid waste program is the formation of the Tim Gober which served at the smallest level in Rukun Warga and Kelurahan. The task the Tim Gober is to clean up garbage and culverts in every Rukun Warga and Kelurahan area. However, the Tim Gober has reduced role of community. In fact, the problem of solid waste needs the involvement of the community because the problem of waste is a social problem.

\section{References}

[1] Emmanuel. Yeboah- Assiamah, ’Decades of public-private partnership in solid waste management. A literature analysis of key lessons drawn from Ghana and India," Management of Environmental Quality: An International Journal, Vol.28, No.1, pp. 78-93, 2017.

[2] Hardep. Rai. Sharma, "Municipal solid waste management in Dessie City, Ethiopia,"Management of Environmental Quality: An International Journal, Vol.24, No.2, pp. 154-164, 2013.

[3] Linda. Sefouhi and Mehdi. Kalla, "Assesment of different methods of treatment for an integrated municipal solid waste management for an Algerian city," Management of Environmental Quality: An International Journal, Vol.25, No.4, pp. 493-504, 2014.

[4] Hacer. Ak and Washington. Braida, "Sustainable municipal solid waste management decision making. Development and implementation of a single score sustainability index," Management of Environmental Quality: An International Journal, Vol.26, No.6, pp. 909-928, 2015.

[5] Dwianto. Indiahono. Kebijakan Publik Berbasis Dynamic Policy Analysis.2009. Yogyakarta,Gava Media

[6] Melpomeni. Vacaloupoulou, George. A. Tsiotras, Katerina. Gotzamani. " Implementing CAF in Public Administration. Best Practices in Europe-Obstacles and Challenges," Benchmarking: An International Journal, Vol.20, No.6, pp. 744-764, 2013.

[7] Pandji. Santosa. Adminsitrasi Publik. Teori dan Aplikasi Good Governance.Bandung, Refika Aditama, 2012.

[8] Frank.Fischer, Gerald.J.Miller, Mara.S.Sidney. "Handbook of Public Policy Analysis.Theory, Politics, and Methods. CRC Press, Boca Raton,FL, 2007.

[9] Helga. Pülzl, Oliver. Treib. " Implementing Public Policy". In Handbook of Public Policy Analysis. Theory, Politics, and Methods. Frank Fisher et al. Eds. CRC Press, Boca Raton,FL: 2007.

[10] Agus. Erwan. Purwanto, Dyah.Ratih. Sulistyastuti, “Implementasi Kebijakan Publik. Konsep dan Aplikasinya di Indonesia," Yogyakarta, Penerbit Gava Media, 2012. 